\title{
Prices and Output in Two Oil-Based Economies: The Dutch Disease in Iran and Nigeria
}

\author{
Ahmad Jazayeri
}

This article analyses some key aspects of structural change in two small oil-based economies, Iran and Nigeria, in the past decade. ' It focuses on the phenomenon sometimes known as the 'Dutch Disease': a booming oil sector, expanding non-traded goods (and services) sector, declining or stagnant nonoil traded goods sector. ${ }^{2}$ In the developed countries this phenomenon has been associated with 'deindustrialisation', while in the less developed countries and especially among OPEC members it has been associated with a fall in domestic production of traded agricultural and industrial goods (except where the product enjoys high tariff barriers and /or import restrictions), and a boost to construction and services (both of which are mostly non-traded in terms of the final product). The analysis is mostly concerned with the short and medium run effects of this phenomenon on resource allocation, income distribution, and the balance of payments. Moreover, given the central role of the government as the primary recipient of oil revenues, governments' macro and sectoral expenditure and pricing policies acquire a particular importance in affecting the direction and the magnitude of the 'Dutch Disease'.

\section{The Framework}

The Dutch Disease model is based upon a threefactor, two-commodity full employment model of production and trade [see Caves and Jones, 1983]. The economy produces two commodities: one traded internationally (i.e. exported or imported), the other traded only domestically since either transport costs or import restrictions prevent the commodity from being internationally traded. The two sectors producing traded and non-traded goods are assumed to have capital in a fixed amount that is given and non-shiftable in the short run. The labour force is fixed

\footnotetext{
'Based on the author's DPhil Thesis 'Prices, Output and Economic Adjustment in Oil Exporting Countries', University of Sussex, 1986.

2 Traded and non-traded here refers to whether or not the commodity in question is traded internationally. Non-traded goods do not refer to subsistence goods which are not traded even domestically.
}

in the aggregate but mobile between the two sectors. Thus we have two specific factors, one mobile factor and two commodities, one internationally traded and the other not. What follows is based upon a change in relative commodity prices and how the consequent price/wage relationships determine factor incomes and sectoral output.

Higher oil income means more foreign exchange earnings, more imports, and a fall in the relative price of traded goods because excess demand raises the price of non-traded goods which are in limited supply in the short run. Higher disposable income, the relative price advantage of traded goods after the boom, plus lower production of traded goods at home, due to the lower relative price, increases the demand for imports and the trade balance deteriorates. The combination of higher levels of imports and higher relative price of non-traded goods results in 'adjustment' or simultaneous internal and external balance. If the real exchange-rate is defined as the relative price of nontraded to traded goods, then the higher relative price of non-traded goods represents an appreciation of the real exchange-rate.

Given the fixed capital stock and perfectly competitive markets, the demand for labour in each sector depends on the wage/price relationship in that sector. The demand for labour depends negatively on the sectoral real product wage (ratio of the wage to the sectoral output price). This means that a rise in the relative price of one sector by more than the wage would increase employment and thereby output in that sector. Increased output would involve higher cost per unit since it would come about through an increase in the sector's use of labour per unit of capital, implying a falling sectoral marginal physical product of labour, because capital stock is fixed. The mobility of labour and the immobility of capital means that a change in the relative price of traded to non-traded goods would have an uneven impact on factor incomes. Labour mobility allows labour to shift out of the traded sector,

IDS Bulletin, 1986, vol 17 no 4, Institute of Development Studies, Sussex 
and thereby maintain or raise its real income, while capital immobility means that returns to capital fall sharply in the sector with a lower relative price and returns to capital in the sector with a higher relative price rise sharply.

To sum up the discussion so far, the oil boom involves an appreciation of the real exchange rate, driven by a rise in the relative price of non-traded goods. The relative price shift causes a reallocation of labour towards the non-traded sector; a rise in the output of non-traded and a fall in the output of traded goods. Returns to capital in non-traded activities rise, while returns in traded activities fall. There is an ambiguous impact on the real wage since the wage in terms of non-traded goods falls, but rises in terms of traded goods, so that the net welfare impact on workers depends upon the composition of the wage basket in terms of traded and non-traded goods.

The explanation so far has been only in terms of output price relative to the price of labour while the price of capital as such has not entered the explanation of output behaviour. A convenient way of introducing the price of capital into the analysis is to distinguish between traded and non-traded capital inputs and consider how the rise in the relative price of nontraded goods (and factors) affects the cost of production and value added in each industry. In a typical developing country, traded capital inputs would mainly consist of imported intermediate commodities such as machinery while non-traded capital inputs would mainly consist of land. A rise in the relative price of non-traded goods (and factors) would raise the cost of production for an activity which uses land intensively, e.g. construction. Similarly, a fall in the relative price of traded goods (and factors) would lower the cost of production in the sectors which rely heavily on imported inputs, e.g. manufacturing.

Going back to our model with three factors and two commodities and distinguishing between traded and non-traded capital inputs, we arrive at four possibilities:

(i) labour combined with imported inputs producing traded goods;

(ii) labour combined with land producing traded goods;

(iii) labour combined with imported inputs producing non-traded goods;

(iv) labour combined with land producing non-traded goods.

Case (i) refers to the domestic manufacturing sector which is non-protected; case (ii) characterises the agricultural sector especially with respect to export crops but also with respect to traded food crops; (iii) refers to the protected manufacturing sector mostly producing import substitutes; case (iv) characterises the construction sector and also nontraded low value or perishable food crops in agriculture. The main point to be emphasised is that in analysing sectoral supply response traded/non-traded capital inputs should also be considered as they affect value added in each industry. For example, a traded goods sector relying on traded inputs would enjoy some offsetting cost reductions given real appreciation of the exchange-rate; its value added would fall by less than if non-traded inputs had a large share in the total cost. In the construction sector, for example, although the price of construction and thereby profits in construction rise with real appreciation, given the importance of land costs in total costs, higher land prices (since land is non-traded) are likely to lower profits.

\section{The Role of Government}

Since oil revenues accrue directly to the central government in oil exporting economies, or at least governments get a major share of the revenues through taxation, it becomes critical to look at how the government spends this money and the impact of such expenditures on the domestic economy. The focus here is on public expenditure policy and its impact on the supply of money, sectoral investment policy, pricing policy, and credit policy. The level of public expenditure is the critical factor behind the rise in aggregate expenditure and the higher price of nontraded goods.

Moreover, both the intersectoral and the intrasectoral allocation of public investments are important to the pattern of sectoral output. The allocation of public investment towards non-traded goods (such as infrastructure) would reinforce the shift of private investment towards the non-traded sector during the boom, and this would constitute a double drain of investment resources away from traded goods, with implications for output in that sector. The main question within each sector is whether the government aims at the gradual transformation of the entire sector, or at a crash modernisation programme which concentrates resources in the highly commercialised and capital intensive sub-sectors, resulting in a skewed pattern of public investment and usually involving adverse effects in terms of output.

With vastly expanded financial resources, the government can effectively implement an agricultural pricing policy programme. The government can set prices both because it can engage in substantial purchases in the domestic market as well as resort to 
imports in order to maintain low prices. A higher or lower official price can therefore become an important signal for changes in the private sector's production incentives.

The effectiveness of the agricultural pricing policy would also depend, however, on whether the agricultural commodities in question are traded or non-traded. If the main food staple is wheat, for example, the possibility of controlling its price is much greater than if the main food is cassava or yam or millet which are not commonly traded internationally because of their high bulk and low value. Even if the main staple food is non-traded, the government can indirectly exert downward pressure on its price through importing near substitutes which are traded.

With higher domestic costs due to the higher price of non-traded goods, domestic exports and import competing goods are no longer competitive at world prices. The higher comparative cost of production in the oil exporting country gives an advantage to competing countries in exporting to the oil economy. Selective tariffs and import controls can provide protection for some traded goods; but if protection is raised sufficiently to ensure that the protected sector is not harmed by the petroleum boom, even though the real exchange-rate has appreciated, the burden of adjustment would then fall entirely on the nonprotected traded sectors.

During the oil boom the government is likely to reduce the average level of tariffs and generally adopt a more liberal import policy, given its favourable balance of payments. Lower tariffs can be regarded as a means of 'adjusting' to the balance of payments surplus since reduction of tariffs and import controls would result in switching of expenditure towards imports and thereby lower the level of foreign exchange reserves.

Government can affect the access of industries to costreducing technology and working capital by allowing or depriving them of credit. Credit policy is also significant for the small farmers who are the main food producers. This is because informal credit is usually difficult to obtain, quite expensive, and leaves little for the farmer for reinvestment. Informal credit usually meets only the working capital requirements of the farmer, leaving a gap as far as credit for adoption of new technologies is concerned.

Consumer subsidies can prevent the relative price rise of specific commodities, and depending upon the importance of that item sectorally, consumer price subsidies can lower the sectoral price level. Consumers would therefore divert the extra funds thus released to the purchase of other non-subsidised goods which could in the aggregate lead to a similar rise in the level of prices. Nevertheless, if the subsidised commodities form a major part of total consumer expenditure, the subsidies would cause the price level to be lower than otherwise and thereby lower the pace of real appreciation.

\section{Iran after the 1973 Oil Boom \\ Rise in aggregate expenditure}

High levels of public expenditure followed the 1973 oil boom in Iran, leading to high levels of aggregate expenditure. High growth rates and relative price stability in the 1960s, plus the success of the fourth plan, had combined to allow a highly optimistic attitude towards planned targets. In early 1974, the current fifth development plan was revised without detailed appraisal, resulting in an increase of 189 per cent in planned investment expenditure. Moreover, the shares in planned expenditure of agriculture, industry, oil and gas declined while the housing and transport (non-traded) sectors had an increased share.

Public consumption expenditures also rose from the equivalent of US $\$ 6.3$ bn in 1973 to US $\$ 9.2$ bn in 1974 [Bank Markazi Iran 1975/76]. These included both military expenditures and expenditure on consumer subsidies (especially for wheat and sugar). Between 1973 and 1978 public consumption expenditures in Iran rose at 12.2 per cent (real terms) per year. Private consumption expenditures rose between 1973 and 1978 by almost 10 per year in real terms, while gross domestic fixed capital formation rose 11 per cent per year.

The rise in domestic expenditure meant a growth in demand for both imports and non-traded goods. Aggregate merchandise imports had an astronomic escalation, rising from US\$ $5.0 \mathrm{bn}$ in 1972 to US $\$ 16.5$ bn in 1977 . Throughout the boom period, serious bottlenecks - notably port congestion - were created as a result of the shortage of non-traded commodities.

Consumer prices in the 1973-78 period rose by at least 12.8 per cent per year. Rising prices of imports do not account for the rate of inflation, since imported inflation was no more than 6 per cent per year in the 1973-78 period. Moreover, some of the important staple foods such as wheat and sugar were heavily subsidised. The real exchange-rate with the US dollar appreciated by 35.3 per cent during the $1973-78$ period

\section{Non-Oil GDP and its Components}

\section{a Relative prices}

Table 1 shows the cumulative changes in the GDP deflator for the main sectors of non-oil GDP before and after the oil boom: 
Table 1

Cumulative percentage price change of main sectors

\begin{tabular}{lcrc}
\hline & & & $\begin{array}{c}\% \text { GDP } \\
(1973-78) \\
\text { weight in } \\
\text { GDP }\end{array}$ \\
\hline Agriculture & $1962 / 72$ & $1973 / 78$ & \\
Manufacture & 22.4 & 88.0 & $(40)$ \\
Construction & 70.0 & 216.7 & $(12)$ \\
Services & 10.5 & 98.4 & $(4)$ \\
\hline
\end{tabular}

Source: Calculated from Bank Markazi Iran, Annual Reports, various years.

Construction had the fastest relative price growth in both periods. Before the boom the prices of manufactured goods declined relative to agriculture but rose relative to services. After the boom however, the relative price of manufactured goods fell compared to all other sectors and agricultural price rises decelerated. Prices of services rose least before the boom and accelerated considerably afterwards.

The acceleration of price increases for construction and the sharp rise in the price of services a re consistent with the economic analysis presented in section one.

\section{b Price of Labour}

The wage-rate, although relatively stable in the 1960 s, rose rapidly after the boom. Wages and salaries in construction rose by 27 per cent per year during the 1973-78 period and rises were similar for all sectors other than government. Wages and salaries of the goverment sector rose only 13.3 per cent per year, but remuneration in the government sector does not reflect market forces, and in any case fringe benefits are not included in these estimates. Therefore, it will be assumed that nominal wages grew at about 27 per cent per year for the economy as a whole, which implied an average annual growth of 13 per cent in the real wage. GDP deflators for the main sectors of the GDP had the following annual trend growth rates: construction 29 per cent, manufacturing 9.7 per cent, services 13.3 per cent and agriculture also 13.3 per cent. In other words, the wage rate rose relative to agriculture, manufacturing and services output prices but it fell relative to construction. The rise in the wage relative to the price of agricultural commodities reflects the cheap food policy which was followed in Iran in this period, a policy which was made possible by the largely traded character of the main staple food in Iran, namely wheat.
The only sector where wages and prices do not conform to the model is in the service sector, since services are usually assumed to be non-traded but wages (in non-government services) rose faster than the GDP deflators for services. Part of the explanation for the relatively slow price rise of services is the large share (about 35 per cent) of total value added in services attributable to government services. The GDP deflator for services rose only as much as wages and salaries in the government sector, or by $13.3 \mathrm{per}$ cent per year. Services also benefited from the presence of traded inputs, e.g. in transport. The transport sector was also highly subsidised and this prevented price rises in that sector. The presence of subsidised services and the large share of government services in total value added in the service sector thus neatly illustrates the impact of government policy upon the relative price predictions of the Dutch Disease model.

\section{Sectoral Growth of Non-oil GDP}

There is also a sharp contrast in the sectoral growth of non-oil GDP before and after the boom. Before the boom, manufacturing and mining grew at 12.3 per cent per year in real terms, followed by services which grew at 11 per cent per year, construction ( 7.6 per cent) and agriculture (4.2 per cent). After the boom, on the other hand, manufacturing (and mines) and agriculture were the lagging sectors, while services and construction achieved rates of growth above the 196272 average. The contrast is especially clear for the manufacturing and agriculture sectors, where output growth fell.

There were three types of industrial performance in Iran after the boom: first, declining industries, second, industries with slow growth (below 10 per cent) and third, industries with fast growth (over 10 per cent). The declining industries were textiles and sugar; industries with slow growth were television assembly, glass making and footwear. The fast growth industries were refrigerators, food processing, passenger cars, tyres, brick-making and paper. Relationships existed among the growth of output, the import dependence of inputs and the level of protection.

Textiles and sugar, for example, both in the low import dependence category (less than 33 per cent of imported inputs in total sales value), did not enjoy price protection, and both industries produce traded commodities. The fast growing industries include brick-making, the output of which is non-traded, highly-protected passenger cars and refrigerators. The other fast growing industries were all in the highlymechanised group. In the slow growth industries, footwear is highly mechanised, while television and sheet glass both enjoyed heavy protection. The 1973- 
78 period, therefore, saw a relative fall in the rate of industrialisation of Iran, but with an uneven impact on the industrial structure. Import dependent, capital intensive, and protected industries grew, while traditional industries such as textiles and sugar declined. The period is one of perverse reindustrialisation rather than de-industrialisation.

Imported capital goods became cheap relative to labour; and the degree of substitution of machinery for labour depended, among other things, on the firm's access to credit, which in turn is very much influenced by the government's credit policy. Industrial lending was confined to a small group of large manufacturing enterprises. The bulk of industrial credit was largely out of reach of smaller manufacturing establishments, which were on the bazaar for their credit and marketing, and more dependent on the local economy for their inputs.

In 1973-78, services had a continuous and stable growth of 16 per cent per year, while construction growth accelerated to 10.9 per cent per year. Although the relative price of construction output rose, its costs also rose rapidly because of the importance of land and labour (non-traded factors of production) in construction. Thus at the initial round of price increases, the price of construction, e.g. houses, goes up and pulls up profits with it. The higher derived demand for construction inputs in turn leads to a rise in wages and land prices and consequently lowers profits in the construction sector.

In the agricultural sector, there was a general stagnation of internationally traded crops in this period, while non-traded crops, such as fresh vegetables, had considerable growth mostly through the activities of the small informal sector. Commodities such as cotton (which was an export crop) declined, since Iranian cotton was non-competitive for export purposes; the country in fact began to import cotton products. Regarding traded crops, especially wheat, production performance was very much influenced by government's maintenance of a cheap food policy made effective through large quantities of imports.

What is, however, more interesting and somewhat puzzling is how the experience of traded crops in the agricultural sector is different from the experience of a number of fast growing industries producing traded goods. One important contrast is in the creditworthiness of agriculture and manufacturing and their differential access to credit and modern technology. The fast-growing capital-intensive industries clearly fared better in these respects.

The Industrial and Mining Development Bank of Iran, and the host of measures to boost the industrial sector initiated in the $1960 \mathrm{~s}$, meant that a number of selected industries with continued access to official support could withstand the adjustment in relative prices and costs much better than other industrial sub-sectors and other traded goods. The agricultural sector, however, inherited a weak and fragmented production structure after land reform and the resultant uncertainties. This, plus the pro-industrial bias of the government, resulted in increased vulnerability of the agricultural sector to rising costs. The agricultural sector generally suffered from lack of credit-worthiness, hence lower access to cost-reducing technology and therefore less ability to respond to Dutch Disease. The examples of modernisation in the sector were few and insignificant. Once again, structural and institutional factors affected the outcome of the Dutch Disease syndrome.

\section{The Case of Nigeria}

The impact of the oil boom on the Nigerian economy was in many respects similar to that in Iran, although differences in the initial conditions, structure, and policy options led to somewhat different results. The unexpected rise in Nigeria's oil income led to a sharp increase in aggregate expenditure, which began with a massive boost to public consumption expenditures. Starting with $1972-73$ as the base year, the index of Nigerian Federal Government spending rose from 100 in 1972-73 to 1,250 in 1977-78. The spending began with a massive wage and salary increase for the civil service, followed by sharp increases in public capital expenditure on large infrastructure, social services, and to a lesser extent on economic services.

Major increases in shares of public investment went to transport, communications, power and education; while agriculture, manufacturing and mines, and health had reduced shares. Both before and after the boom, the share of infrastructure and services was considerable; and in the post-boom period, about 80 per cent of all public investments were in physical and social infrastructure and public services - all reinforcing the movement of resources towards nontraded goods. The allocation of 2.5 per cent of the government's budget in 1981 and 1982 for the establishment of a new capital city at Abuja was a supreme example of how public funds are diverted towards the production of non-traded goods.

Of the remaining 20 per cent allocated to agriculture and industry, the bulk was in large projects. In industry, almost half the allocations were for the build-up of the steel industry, while small-scale industries had planned allocations of less than five per cent in the Fourth Plan. In spite of lack of encouragement by the government, the number of small-scale industries grew at an average rate of 32 per 
cent per year between 1974 and 1978. This is an important point concerning the type of development which is encouraged by government policy. Expenditure is largely concentrated in non-traded and large expensive projects in the traded sectors of the economy, while the small-scale sector is badly neglected; it is the small industries which are the most domestic resource-based and have a great potential for viable industrial diversification.

Of all public investments in the $1975-79$ period, agriculture received only 7.1 per cent of all allocations. If irrigation is also included under agricultural investment, then the share goes up to 9.9 per cent. In Federal Government allocations alone, the share drops to 2.4 per cent ( 5.9 with irrigation) while state governments give greater priority to this sector, allocating a little over 10 per cent of their budgets. Again within agriculture, the bulk of investment is in large-scale food crop projects and large-scale irrigation. Interestingly, the share of irrigation alone is larger than the rest of agriculture combined in the Federal Government's actual capital spending in 1980. Also, over 80 per cent of so-called agricultural investment by the Federal Government has been in fertiliser procurement and distribution, reflecting a highly skewed pattern of expenditure.

\section{Gross Domestic Product and its Components}

According to official statistics, between 1973 and 1981, GDP in current prices rose at 15.6 per cent per year and non-oil GDP rose at almost the same rate of 15.7 per cent. The official estimate of the growth of output of the agricultural sector is likely to include an under-estimate for food crops. Inflation reduced real GDP growth to 3.2 per cent and real non-oil GDP growth to 4.3 per cent per year.

In the same period, real agricultural out put fell by two per cent per year, while the GDP deflator for agriculture rose at 14.4 per cent per year. Changes in the agricultural output differ greatly year by year. Nominal wages in agriculture rose on average at 20 per cent per year between 1973 and 1980 , or at 14.5 per cent if we take the $1973-79$ period. Real wages in agriculture only rose in the first two years after the oil boom, declined until 1979, and then suddenly rose again in 1980. The contribution of agriculture to GDP at constant prices declined from 31 per cent in 1973 to 22 per cent in 1981.

Within agriculture, crop production had the worst decline of three per cent per year, although food crops fared better than export crops. The only export crop showing positive production growth was palm oil. Livestock and fishing, however, were growing gradually at one per cent per year. It appears that the national accounts are based on the Federal Office of Statistics data, which have the most pessimistic estimates regarding crop production, particularly food crops. Using alternative sources such as the USDA data, for example, agricultural output would not have fallen as much as indicated by the national accounts.

Manufacturing as a whole grew by 9.4 per cent per year in real terms, while manufacturing prices grew at 9.9 per cent per year, lagging behind the average rate of inflation in the economy. Moreover, the growth of manufacturing was highly uneven.

Construction and building had a highly unstable growth rate. Rapid price rises in 1974 and 1975 were followed by a sudden growth of output in 1976 and 1977 , and by a period of recession in 1978 and 1979 , and then picked up again in 1980 . Steep price rises in 1974 and 1975 in the construction sector were followed by a period of continuous decline of the real price from 1977 onwards. The output of the sector grew on average at 7.0 per cent per year, and prices at 8.7 per cent per year, which is below the GDP deflator for the economy as a whole. The share of the construction and building sector in GDP rose from 10 per cent in 1973 to 12 per cent in 1981 .

The price index of the trade sector rose by 14.6 per cent per year, which is above the average inflation rate for the economy; while the prices of services as a whole grew almost at par with the growth of the GDP deflator. Government services are also part of the service sector, and the Udoji awards of 1975 almost doubled the salaries of the civil servants. The wholesale and retail trade's contribution to GDP rose from 19 per cent in 1973 to 22 per cent in 1981 , almost matching the agricultural sector. The service sector as a whole increased its share from 31 per cent of GDP in 1973 to 37 per cent in 1981 .

For the 1973-81 period as a whole, we find that the GDP deflator for trade, transport and agriculture rose above the average GDP deflator for the economy, while manufacturing and - surprisingly - construction rose less than the average GDP deflator. A weighted average of the nominal wage growth for the 1973-78 period indicates that nominal wages rose at 15 per cent compound per year in the 1973-80 period, which is above the average growth of the non-oil GDP deflator. The growth of nominal wages, however, is practically the same as the growth of GDP deflator for agriculture, trade and transport. In other words, wages were stagnant relative to price rises in these three sectors, while they rose relative to manufacturing and construction prices. In terms of sectoral price rises and the relative real wage, the Nigerian outcome is different from Iran, where agricultural prices rose less 
than the non-oil GDP deflator, while in Nigeria they exceeded it. Also, in Iran, construction prices had the fastest growth of all, while in Nigeria they rose below the average rate of inflation. The experience of the transport and trade sectors also differed, with prices lagging behind inflation in Iran, but outpacing inflation in Nigeria. In both cases, however, general manufacturing sector prices rose less than prices in general.

Regarding wages, there is also an interesting contrast. Wages rose in Iran in terms of agriculture, manufacturing and service prices, while they fell relative to construction. In Nigeria, the wage rise was only clear relative to manufacturing and construction prices, while wages did not rise relative to prices in agriculture and services.

This again shows the importance of government policy in determining the outcome of adjustment. Overall, real wages rose more in Iran than in Nigeria. In Iran, the government followed an effective, cheap food policy and the prices of importable staple foods, such as wheat, declined in real terms in the 1970s. In Nigeria on the other hand, the index of agricultural prices generally rose above average inflation in the economy; and also food prices as a whole rose faster than the consumer price index. Moreover, in Nigeria the real exchange-rate appreciated by more than double that of Iran. The rise in food prices in Nigeria and the consequent rise in the consumer price index were greater than in Iran. This is an important result which shows the key significance of sector-specific government policies (in this case food pricing policy) in determining the outcome of the higher levels of expenditure for the economy and the intensity of the appreciation of the real exchange-rate. A key result which emerges at this point is the predominantly nontraded character of food in Nigeria (eg cassava, millet, etc.), in contrast to Iran where massive food imports kept food prices below the rate of inflation.

The growth of the manufacturing sector, as we also found for Iran, is not fully compatible with the model unless we introduce government intervention in the form of tariffs and/or subsidies to the traded manufacturing sector; these in fact have been provided in both countries. In Nigeria, the sectors with least price rise appear to have had the fastest real growth (manufacturing and construction), while sectors with the fastest price increases had the lowest growth rates (agriculture and services). In other words, in terms of explaining real output growth, the model presented at the beginning does not allow very definite conclusions to be drawn. By introducing the role of government one can obtain more definite results which, although modifying the predictions of the model, maintain its overall strength in explaining economic performance in these two countries.

\section{Conclusions}

This article has discussed the theoretical structure and two empirical applications of the so-called 'Dutch Disease' model. It has been shown that both Iran and Nigeria followed a high expenditure path for adjusting to the accumulation of financial surpluses in their balance of payments. The high level of expenditure in both cases was the result of rapid increases in public expenditure, especially on the non-traded sectors such as infrastructure, housing and transport. Increase in public expenditure was followed by an increase in private expenditure. The rise in overall aggregate expenditure meant an increase in the relative price of non-traded goods.

The theory predicted that returns to capital in nontraded activities would exceed the rise in non-traded prices, which in turn would exceed the rise in the wage rate; each of these would exceed the rise in prices and returns in internationally traded activities.

The observed outcomes, however, were somewhat different, mainly because of government intervention. In Iran, wages rose relative to agriculture, manufacturing and services prices, but fell relative to construction prices. The rise in wages relative to agriculture prices reflects the cheap food policy in Iran which was made possible by (a) the financial strength of the government and (b) the largely traded character of food in Iran (especially wheat). Prices of services were very much influenced by direct government intervention, in the form of consumer price subsidies on public transport, and the large share of government in the total value added in the service sector. In spite of the non-traded character of services, their prices did not rise faster than wage-rates because of government intervention. In Nigeria, on the other hand, agriculture had the fastest price rise, and this can be explained largely in terms of the non-traded character of food staples in Nigeria and the absence of an effective cheap food policy. Wages rose in parallel to the rise in food prices, as did the price of services, reflecting the fact that, in large part, income from services is identical to the wage because of the selfemployed and non-traded character of most services.

On the output side, the role of government intervention is critical, since with the exception of construction in Iran the sectors with the least price rise had the fastest real growth rates. In Nigeria, in contrast to Iran, the bulk of construction activities has been in non-residential building and specifically in publicly-sponsored construction in physical infrastructure. Moreover, protection and promotion of selected manufacturing activities has allowed main- 
tenance of high profit margins in spite of the erosion of margins caused by the faster growth of prices than wages.

\section{References}

Bank Markazi, Iran, Annual Report and Balance Sheet. various years.

Caves, R. E., and R. W. Jones, 1983, World Trade and Payments: an introduction, Little, Brown, Boston (Mass.) 3rd edition, ch. 6 